\title{
Tempat Ibadah Tangguh Era New Normal Desa Balun Kecamatan Turi Kabupaten Lamongan
}

\author{
Tough Places of Worship for New Normal Era on Balun Village Turi District \\ Lamongan Regency \\ Yanuangga Galahartlambang ${ }^{1}$, Titik Khotiah ${ }^{2}$, Jumain ${ }^{3}$ \\ ${ }_{1,2,3}$ Teknologi Informasi, Fakultas Teknik, \\ Institut Teknologi dan Bisnis Ahmad Dahlan Lamongan, Indonesia \\ e-mail:. 1 yanuangga@gmail.com, ${ }^{2}$ titikaye@gmail.com, ${ }^{3}$ jumain.dj@gmail.com
}

\begin{abstract}
Abstrak (Bahasa Indonesia)
Kehidupan manusia di seluruh dunia berubah. Perubahan ini akibat virus covid-19 yang memaksa kondisi baru. Dalam hal ini, secara global kehidupan sosial tercipta suatu tatanan baru. Kehidupan manusia di mana pun memasuki ruang bernama Normal Baru.Tempat ibadah menjadi salah satu sarana umum tempat berkerumunan warga sehingga perlu menjadi perhatian dalam penerapan protokol kesehatan pencegahan Covid-19.Tempat ibadah tangguh dapat dilihat dari kesiapan dalam menaati protokol yang telah di siapkan pemerintah dalam pencegahan Covid-19. Di desa Balun memiliki 3 tempat ibadah yaitu masjid, pura dan greja dan menjadi salah satu tempat ibadah tanggung di kabupaten Lamongan.
\end{abstract}

Kata kunci-Protokol Kesehatan,Normal Baru, Tempat Ibadah Tangguh

\section{Abstract (Bahasa inggris)}

Human life around the world is changing. This change is due to the Covid-19 virus which forced new conditions. In this case, globally social life creates a new order. Human life everywhere enters a space called the New Normal. Places of worship are one of the public facilities for gathering residents so that it needs to be a concern in implementing the Covid-19 prevention health protocol. A tough place of worship can be seen from the readiness to comply with the protocols that have been prepared by the government in implementing the COVID-19 prevention protocol. Covid-19 prevention. In the village of Balun has 3 places of worship, namely mosques, temples and churches and is one of the places of worship in Lamongan district.

Keyword - Health Protocol, New Normal, Tough Place of Worship

\section{PENDAHULUAN}

Pada masa ini, Dalam beberapa waktu terakhir, muncul istilah baru yaitu normal baru Siapapun yang memulai kata Normal Baru ini, jelas ada benang merah kesepahaman. Normal Baru, secara umum disepakati tanpa sadar, yakni menerangkan suatu kondisi yang terbentuk akibat lamanya kehidupan sosial masyarakat selama Covid-19.

Beberapa penelitian menjelaskan, suatu kebiasaan yang terus menerus dilakukan akan menjadi kebiasaan baru. Untuk hal ini, hampir semua peneliti sosial duduk dalam pendapat yang sama. Perbedaannya terletak berapa lama kebiasaan baru itu terbentuk. Beberapa ahli yang menetapkan berapa lama kebiasaan baru tercipta antara lain, Dr. Maxwell Maltz yang dari buku Psychocybernetics menetapkan 21 hari untuk membentuk kebiasaan baru (Maltz, 2015). Namun, Phillippa Lally dari University College London mengatakan penelitiannya menetapkan rata-rata 66 hari untuk merubah pembiasaan menjadi kebiasaan sebagaimana publikasi penelitiannya dalam European Journal of Social Psychology (researchgate.net). 
Pendapat dua ahli ini juga dimuat oleh Kompas (12 Juli 2018) dengan judul 'Berapa Lama Waktu Yang Dibutuhkan Untuk Mengubah Kebiasaan?' Tetapi, seorang peserta diskusi dalam jaringan (daring) dengan aplikasi zoom sempat membatah penggunaan kata Normal Baru. Menurutnya, kata yang tepat untuk kondisi akibat covid-19 adalah apnormal. Bisa saja asumsi itu benar.

Protokol kesehatan pada tempat ibadah telah diatur oleh Menteri Menteri Kesehatan (Menkes). Aturan itu tertuang dalam Keputusan Menteri Kesehatan Nomor HK.01.07/MENKES/382/2020 tentang Protokol Kesehatan bagi Masyarakat di Tempat dan Fasilitas Umum yang disahkan pada 19 Juni 2020. "Rumah ibadah merupakan suatu tempat/bangunan digunakan oleh umat beragama untuk beribadah menurut ajaran agama atau kepercayaan mereka masing-masing. Dalam kegiatan di rumah ibadah dapat melibatkan sejumlah orang yang berkumpul dalam satu lokasi sehingga berpotensi terjadinya risiko penularan COVID-19. Untuk itu, agar tetap dapat beribadah di masa pandemi COVID-19 ini perlu dilakukan upaya pencegahan dan pengendalian dengan penerapan protokol kesehatan untuk meminimalkan risiko penularan," demikian bunyi pedoman protokol kesehatan terkait rumah ibadah. Dikutip dari detikcom, Jumat (19/6/2020).

Di desa Balun, Tiga tempat ibadah yang terdiri dari Pura, Masjid dan Gereja diresmikan oleh Forkopimda setempat menjadi tempat ibadah tangguh.Peresmian itu dilakukan, setelah sebelumnya dilakukan uji kelayakan tempat peribadatan yang dinilai mampu menerapkan protokol kesehatan. Dikutip dari Berita Publik .Info (Lamongan), (13 Agustus 2020).

\section{METODE PELAKSANAAN}

Metode pelaksaan pada kegiatan ini yaitu mengumpulkan informasi melalui pengamatan, interaksi langsung tentang protokol kesehatan yang sudah disediakan atau dilakukan di setiap tempat ibadah di desa Balun. Pengamatan yang digunakan yaitu observasi secara langsung untuk mengamati situasi di desa Balun. Wawancara digunanakan untuk mendapatkan informasi mengenai penerapan protokol kesehatan tempat ibadah tangguh pada masa new normal serta kendala atau kekurangan dari setiap tempat ibadah.

Penelitian ini bermaksud untuk menggambarkan tentang kondisi yang terjadi yang kemudian di ungkapkan kembali melalui analisis secara kritis mengenai masalah yang ada, Sehingga terjadi pemecahan masalah.

\section{HASIL DAN PEMBAHASAN}

Pada era new normal masyarakat harus menjalani kehidupan dengan kebiasaan-kebiasaan baru ketika beraktifiktas diluar rumah seperti ibadah, kerja, interkasi dengan tetangga dll. Surat Edaran Menteri Agama Nomor 15 Tahun 2020 telah ditandatangani pada Jumat (29/5/2020). Surat Edaran tersebut membahas tentang Panduan Penyelenggaraan Kegiatan Keagamaan di Rumah Ibadah dalam Mewujudkan Masyarakat Produktif dan Aman dari COVID-19 di Masa Pendemi.

Implementasi penerapan protokol kesehatan pencegahan Covid-19 pada new nomal di masing masing tempat ibadah di desa Balun yakni sebagai berikut :

1. Masjid "Miftahul Huda"

JAMU: Jurnal Abdi Masyarakat UMUS: first_page - end_page 


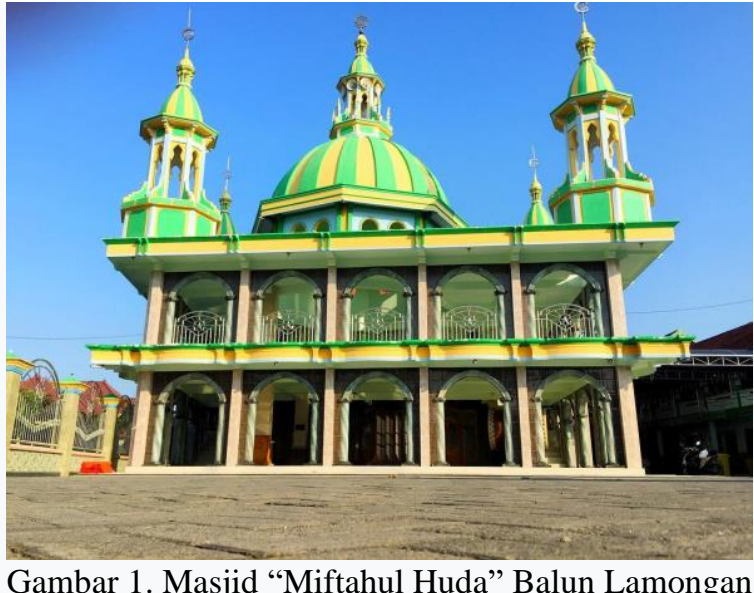

Di masjid tersebut penerapan protokol kesehatan pencegahan Covid-19 sudah dijalankan dengan baik. Ketersediaan saran cuci tangan di halaman parkir yang cukup banyak, terdapat 5 sarana cuci tangan dan 1 cuci tangan dari Pemkab Lamongan sehingga masyarakat yang mau beribadah setelah parkir kendaraan dapat langsung cuci tangan. Saat beribadah atau memasuki area masjid diwajibkan memakai masker dan jaga jarak. Pengurus masjid mengatur jarak ketika terdapat ibadah sholat pada hari besar seperti idul fitri, idul adha, sholat jum'at ataupun sholat wajib sampai area lapangan di depan masjid digunakan agar jama'ah tidak berdekatan. Pengecekan suhu badan selalu dilaksanakan saat memasuki halaman masjid, penyemprotan disenfektan dan tidak berjabat tangan saat selesai sholat. Tetapi masih terdapat masyarakat yang tidak memakai masker dan cuci tangan ketika masuk ke area masjid. Dikarenakan masjid berdekatan dengan bascam atau tempat berkumpulnya remaja masjid dan sekolah. Masih terdapat kerumunan pemuda maupun warga sekitar.

\section{Pura "Sweta Maha Suci"}

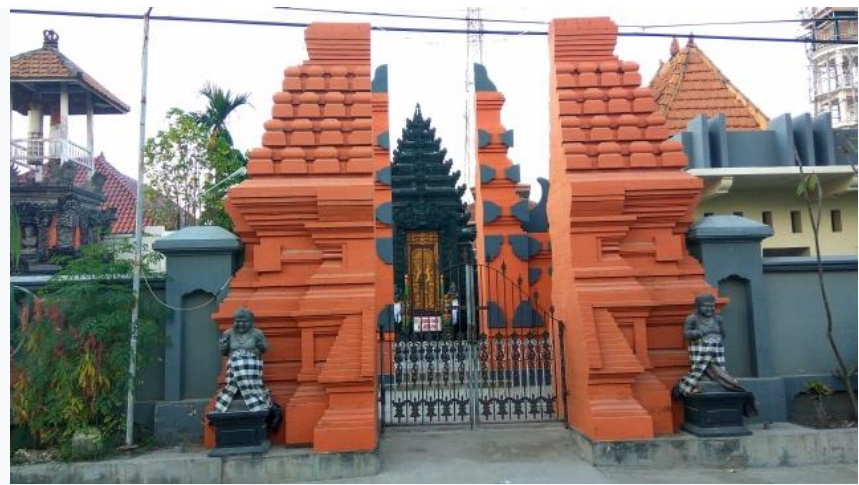

Gambar 2. Pura "Sweta Maha Suci” Balun Lamongan

Di pura tersebut Di masjid tersebut penerapan protokol kesehatan pencegahan Covid-19 sudah dijalankan dengan baik. Terdapat sarana cuci tangan di halaman maupun di dalam kawasan pura, setiap jama'ah diwajibkan selalu cuci tangan saat memasuki pura dan selalu memakai masker, pengurus juga memberi tanda silang $\mathrm{X}$ di dalam pura agar antar jama'ah tidak berdekatan saat beribadah dan juga pengecekan suhu bandan serta penyemprotan disenfektan. Masih juga terdapat jama'ah yang tidak memakai masker dan cuci tangan ketika masuk ke area pura.

\section{Gereja "GKJW"}

Di gereja tersebut penerapan protokol kesehatan pencegahan Covid-19 sudah dijalankan dengan baik. Terdapat sarana cuci tangan didepan pintu masuk, sehingga jama'at yang memasuki greja diwajibkan cuci tangan. Pengurus juga mewajibkan selalu menggunakan 
masker dan memberikan tanda silang $\mathrm{X}$ di tempat kursi para jama'at agar tidak saling berdekatan. Selalu melakukan kegiatan penyemprotan disenfektan dan pengecekan suhu badan. Tetapi masih terdapat kurumunan dikarenakan GKJW dijadikan salah satu tempat berkumpulnya remaja gereja dan masih terdapat jama'at tidak memakai masker dan cuci tangan saat memasuki gereja.

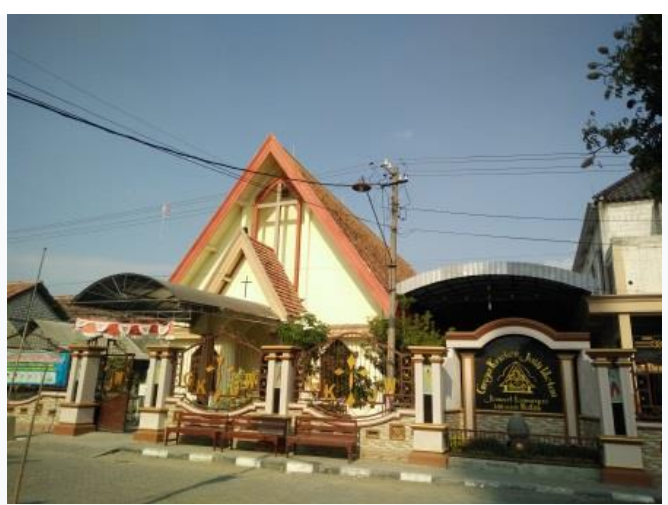

Gambar 3. Gereja “GKJW” Balun Lamongan

Dari penerapan protokol kesehatan pencegahan Covid-19 yang terdapat di setiap tempat ibadah masih memiliki kekurangan atau hambatan yang sama yaitu masalah kesadaran masyarakat yang kurang. Maka dari itu, disusun kegiatan-kegiatan yang bertujuan untuk membangun kesadaran masyarakat dalam pandemi ini, serta penerapan protokol kesehatan tempat ibadah tangguh Pada masa new normal.

\section{a. Kegiatan Edukasi}

Kegiatan Edukasi kepada masyarakat di desa Balun yang berupa memasang banner edukasi pencegahan Covid-19, Edukasi lewat media medsos, dan Edukasi dengan interaksi langsung kepada masyarakat dan jama'ah setiap tempat ibadah untuk mengingatkan tentang pentingnya protokol kesehatan pencegahan Covid-19 menjadi kegiatan yang sangat penting untuk membangun kesadaran akan pentingnya menaati protokol kesehatan yang telah ditetapkan.
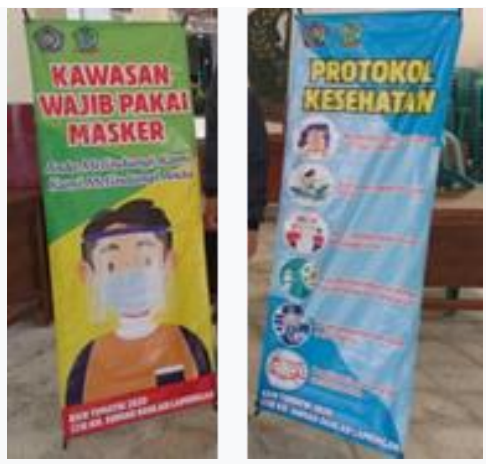

Gambar 4. Edukasi Banner Pencegahan Covid-19

b. Kegiatan Disenfektan

Kegiatan penyempotan disenfektan di sekitar tempat ibadah, kegiatan penyemprotan ini yang bertujuan mematikan bakteri Covid-19 yang menempel di benda maupun di udara sehingga memutus rantai penularan Covid-19 serta memberikan edukasi agar dilakukan penyemprotan disenfektan sebelum atau sesudah dilakukannya ibadah sesuai dengan peraturan yang ditetapkan pemerintah tentang protokol kesehatan pencegahan Covid-19 di tempat ibadah. c. Kegiatan pembuatan sarana cuci tangan "Wastafel Portabel” 
Kegiatan pembuatan sarana cuci tangan "Wastafel Portabel” bertujuan untuk membantu dalam ketersediaan sarana cuci tangan dan membangun kebiasan warga untuk selalu cuci tangan. Cuci tangan merupakan program pengendalian infeksi dan memcegah penularan dalam masa pandemi ini. Maka dari itu diwajibkan selalu cuci tangan setiap mengawali kegiatan maupun mengakhir kegiatan termasuk dalam beribadah.

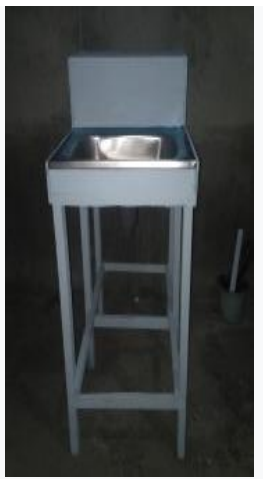

Gambar 5. Kegiatan pembuatan sarana cuci tangan Wastafel Portabel

Kesadaran masyarakat mulai meningkat untuk memematuhi protokol yang telah ditetapkan di tempat ibadah dan tidak terdapat masyarakat atau jama'ah yang tidak mematuhi protokol.Sehingga memberikan rasa aman kepada orang lain atau orang disekitarnya serta membantu menjadikan tempat ibadah masing-masing tetap menjadi tempat ibadah tangguh yang telah ditetapkan pada tanggal 13 Agustus 2020 oleh bapak Bupati Lamongan.

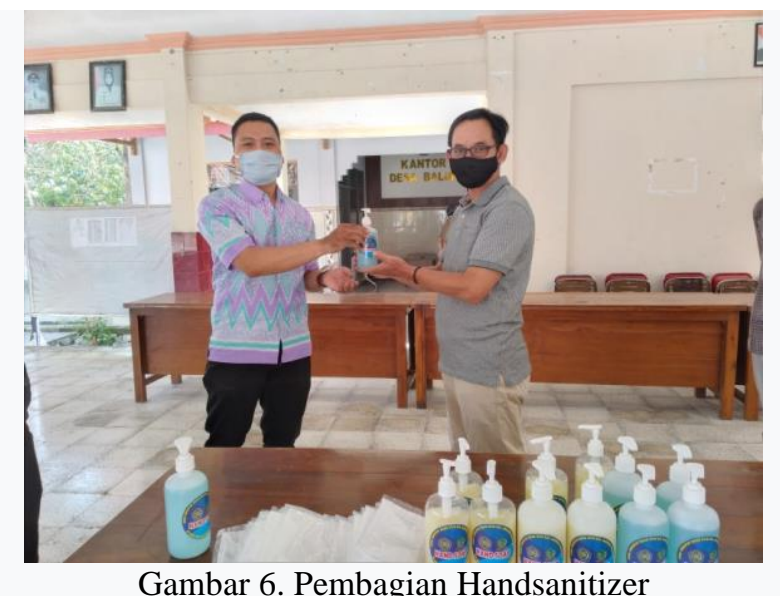

KESIMPULAN

Di desa Balun, Tiga tempat ibadah yang terdiri dari Pura, Masjid dan Gereja diresmikan oleh Forkopimda setempat menjadi tempat ibadah tangguh. Sarana dan Prasarana untuk menunjang protokol kesehatan pencegahan Covid-19 sudah terpenuhi dengan baik. Dari penerapan protokol kesehatan pencegahan Covid-19 yang terdapat di setiap tempat ibadah masih memiliki kekurangan atau hambatan yang sama yaitu masalah kesadaran masyarakat yang kurang. Dari hasil, kegiatan-kegitan yang telah dilakukan, sangat membantu pengurus masing-masing tempat ibadah, dan membantu membangun kesadaran masyarakat agar menjadikan kebiasaan memakai masker serta cuci tangan dalam masa new normal. 


\section{DAFTAR PUSTAKA}

Soemarwoto, O. 1994. Ekologi Lingkungan Hidup dan Pembangunan. Bandung: Djambatan

Kementrian Pendidikan dan Kebudayaan. Panduan Program KKN-PPM, Direktorat Penelitian dan Pengabdian Kepada Masyarakat, Dirjen DIKTI.

AndrianHabibi. 2020.Normal Baru Pasca Covid-19. Jakarta. Adalah: Buletin Hukum dan Keadilan, Vol.4, No.1

A. Helmy Faisal dkk, Ahmad Erani Yustika. Pandemi Corona: Virus Deglobalisasi Masa Depan Perekonomian Global dan Nasional. 1ed. Bogor: IPB Press, 2020

Agnes Goni, Mersty Rindengan, Amania Mogot. "DAYA SAINS: Jurnal Pengabdian Kepada Masyarakat" Volume 1 | Nomor 1 | Agustus |2018: 2- 3

Ariyawati, Ni Putu Ari. Resielensi Bisnis Pada UMKM di Era New Normal Baru sebagai Upaya Kemandirian Ekonomi. 1 ed. Sulawesi selatan: Yayasan Ahmar Cendikia Indonesia, 2020

Endang Bidayani, Dwi Rosalina. "Jurnal Abdi Insani Umum." Maret 2017 Vol. 4 No. 1 (27): Hlm. 74-75

Ilmar, Aminuddin. Memahami Kebijakan Pemerintah Dalam Menangani Covid-19. 2ed. Makassar: Phinatama media, 2020

Irawan, Edi. Model Pengabdian Berbasis Kompetisi. 1 ed. Yogyakarta: Mei 2020

Koko Handoko, Pastima Simanjuntak. "MATAPPA: Jurnal Pengabdian Kepada Masyarakat 'Pembinaan Pemanfaatan Teknologi Informasi Dan Komunikasi Pada Masyarakat Pulau Temoyong Batam Kepulauan Riau" 2 Nomor 1, Maret 2019

Nikoyan, Fyka, Iswandi, Alwi. "Jurnal Pengabdian Masyarakat Ilmu Terapan" VOL. 2, No. 1, April 2020

Oos M. Anwas. Pemberdayaan Masyarakat di Era Global. Bandung: Alfabeta, 2013

Risnawati, Nanik. "Profil Umk, Permasalahan Dan Upaya Pemberdayaannya Di Kabupaten Sumedang Coopetition" Vol 9, Nomor 1, Mei 2018

Sayuri, Mustamin Fattah. "Jurnal Penelitian." 2019 Vol.11, No. 1 (t.t.): 53. https://doi.org/10.21093/fj.v11il.1380

Permana, A. ., Yono, R. R. ., Ubaedillah, U., \& Sucipto, H. . (2021). Penyuluhan dan Pelatihan Pemanfaatan E-Commerce di Desa Cikakak Kecamatan Banjarharjo. JAMU : Jurnal Abdi Masyarakat UMUS, 2(01), 59-64. https://doi.org/10.46772/jamu.v1i02.547 